\title{
Correction to: Rethinking Critique: Becoming Clinician
}

\section{Leticia Da Costa Paes ${ }^{1}$}

Published online: 5 November 2019

(c) Springer Nature B.V. 2019

\section{Correction to: Law and Critique https://doi.org/10.1007/s10978-019-09249-4}

The article Rethinking Critique: Becoming Clinician, written by Leticia Da Costa Paes, was originally published electronically on the publisher's internet portal (currently SpringerLink) on 24 September 2019 with open access.

With the author(s)' decision to step back from Open Choice, the copyright of the article changed on November 2019 to (C) Springer Nature B.V. 2019 and the article is forthwith distributed under the terms of copyright.

The original article has been corrected.

Publisher's Note Springer Nature remains neutral with regard to jurisdictional claims in published maps and institutional affiliations.

The original article can be found online at https://doi.org/10.1007/s10978-019-09249-4.

Leticia Da Costa Paes

Lpaes01@mail.bbk.ac.uk

1 School of Law, Birkbeck, University of London, Malet Street, London WC1E 7HX, UK 